Agrisaintifika

Jurnal Ilmu-Ilmu Pertanian

Vol. 2, No. 1, 2018

\title{
Analisis Menurunnya Minat Petani Menanam Padi Organik dengan Pendekatan Fishbone Diagram Di Kabupaten Ngawi
}

\author{
Ari Leksono Marhaen Widodo, Mohd Harisudin, dan Agustono \\ Fakultas Pertanian, Program Studi Agribisnis, Universitas Sebelas Maret \\ JI. Ir. Sutami No.36 A Kentingan Surakarta 57126 Telp./Fax (0271) \\ 637457marhaenw@gmail.com
}

\begin{abstract}
ABSTRAK
Penelitian ini dilakukan dengan tujuan untuk menganalisis keragaan pendapatan petani padi organik dan petani padi konvensional, mengetahui faktor penyebab apa yang paling utama menyebabkan menurunnya minat petani menanam padi organik, serta mencari tindakan apa yang dapat meningkatkan minat petani menanam padi organik. Metode dasar yang digunakan adalah metode deskriptif dengan teknik pengambilan data menggunakan teknik observasi, wawancara, kuesioner, serta dokumen dan pencatatan. Data yang digunakan adalah data primer dan sekunder. Penelitian dilakukan di Kabupaten Ngawi. Metode analisis data yang digunakan dalam penelitian ini adalah analisis pendapatan usahatani, analisis efisiensi usahatani, serta analisis fishbone diagram. Berdasarkan hasil analisis menunjukan bahwa pendapatan usahatani padi konvensional lebih tinggi apabila dibandingkan dengan usahatani padi organik dengan nilai Rp. 18.131.817,66,-/ha/MT berbanding dengan Rp. 11.330.399,35,-/ha/MT. Analisis Efisiensi menunjukan bahwa kedua jenis usahatani telah efisien namun nilai efisiensi usahatani padi konvensional lebih tinggi apabila dibandingkan dengan usahatani padi organik dengan nilai 3,09/MT berbanding dengan 2,01/MT . Berdasarkan analisis fishbone diagram menunjukan bahwa faktor yang paling berpengaruh adalah dari faktor manusia yaitu dengan permasalahan penerimaan uang yang terlambat.
\end{abstract}

Kata Kunci : Efisiensi Usahatani, Fishbone Diagram, Padi Organik, Pendapatan, Petani.

\section{ABSTRACT}

This study aims to analyze the performances of organic rice farmers and conventional rice farmers, to find out the cause factors decreasing interest of farmers to plant organic rice and to find the way which can increase the interest of farmers to grow organic rice. The basic method used is a descriptive method with data retrieval technique using observation, interview, also documentation and archiving technique. The data used are primary and secondary data. The study was conducted in Ngawi District. Data analysis method used in this research is farm income analysis, farm efficiency analysis, and fishbone diagram analysis. The results show that the income from conventional rice farming is higher when compared with organic rice farming with a value of Rp. 18,131,817.66, - / ha / MT compared to Rp. 11.330.399,35, - / ha / MT. Analysis Efficiency shows that both types of farming have been efficient but the value of conventional rice farming efficiency is higher when compared with organic rice farming with 3.09 / MT value compared to 2.01 / MT. Based on the analysis of fishbone diagram shows that the most influential factor is the human factor that is with the problem of late receipt of money.

Keywords: Efficiency Farm, Farmer, Fishbone Diagram, Income, Rice Organic.

\section{PENDAHULUAN}

Gaya hidup sehat merupakan trend baru yang sedang berkembang di masyarakat. Menurut Soeleman (2013), salah satu aktualisasi gaya hidup sehat adalah gaya hidup organik, yaitu gaya hidup dengan mengkonsumsi atau menggunakan produkproduk organik. Masyarakat dengan gaya hidup organik sangat selektif dengan pemilihan produk yang dikonsumsinya, salah satunya adalah beras yang merupakan produk pertanian yang menjadi kebutuhan primer.

Potensi pertanian organik di Indonesia cukup besar. Menurut Mayrowani (2012), potensi pertanian organik di Indonesia masih luas. Hal ini terlihat dari ketersediaan lahan untuk pertanian organik sangat besar. Sekitar 
118,2 juta ha, yang tersebar di berbagai daerah, memiliki peluang untuk digunakan sebagai lahan pertanian organik.Salah satu daerah yang membudidayakan padi organik adalah Kabupaten Ngawi. Kabupaten Ngawi pun merupakan salah satu kabupaten yang menjadi lumbung padi di Jawa Timur. Luas lahan sawah di Kabupaten Ngawi mencapai $38,94 \%$ sebesar 504,76 Ha dari seluruh luas wilayah Kabupaten Ngawi yaitu sebesar $1.295,98 \mathrm{Ha}$. (BPS, 2014)

Berdasarkan Tabel 1 dapat diketahui bahwa Kabupaten Ngawi menempati posisi ketiga sebagai kabupaten sentra penghasil padi. Mengenai komoditi padi organik, pemerintah Kabupaten Ngawi pun sangat mendukung untuk para petaninya menanam komoditi padi organik. Hal ini terlihat dari adanya Badan Ketahanan Pangan yang melaksanakan program Agribisnis Padi Organik (APO) dan Ketahanan Pangan. Dinas Tanaman Pangan dan Hortikultura yang melaksanakan gerakan $1000 \mathrm{Ha}$ penanaman padi organik (RTRW Kabupaten Ngawi, 2010).

Tabel 1.Luas Panen, Produktivitas, dan Produksi Padi Sawah di Provinsi Jawa Timur Tahun 2013

\begin{tabular}{lccc}
\hline Kabupaten/Kota & $\begin{array}{c}\text { Luas Panen } \\
(\mathbf{H a})\end{array}$ & $\begin{array}{c}\text { Produktivitas } \\
\text { (Kw/Ha) }\end{array}$ & $\begin{array}{c}\text { Produksi } \\
\text { (Ton) }\end{array}$ \\
\hline 01. Jember & 161.851 & 59,26 & 959.082 \\
02. Lamongan & 135.925 & 58,68 & 797.596 \\
03. Ngawi & $\mathbf{1 2 0 . 9 2 9}$ & $\mathbf{6 3 . 6 8}$ & $\mathbf{7 7 0 . 1 2 5}$ \\
04. Bojonegoro & 134.546 & 57,13 & 768.656 \\
05. Banyuwangi & 111.446 & 62,48 & 696.279 \\
\hline \multicolumn{1}{c}{ Jumlah } & $\mathbf{1 . 8 9 7 . 8 1 6}$ & $\mathbf{6 0 , 0 1}$ & $\mathbf{1 1 . 3 8 7 . 9 0 3}$ \\
\hline
\end{tabular}

Sumber: BPS Provinsi Jawa Timur Tahun 2014

Kabupaten Ngawi juga memiliki wadah yang membantu perkembangan pertanian padi organik, yaitu Komunitas Ngawi Organik Center (KNOC). Lembaga ini cukup perperan penting dalam mewujudkan pertanian organik di Kabupaten Ngawi. Lembaga yang didirikan pada tahun 2012 ini merupakan lembaga swadaya masyarakat. Peksanaan pertanian organik tidak selalu berjalan lacar. Menurut Purwanto (2012) masalah utama yang dihadapi oleh pertanian secara keseluruhan adalah adanya berbagai masalah lingkungan khususnya tentang perubahan iklim global dengan berbagai dampaknya. Menurut Andoko (2008), Pemikiran petani untuk mendapatkan keuntungan yang besar dalam waktu yang singkat juga membuat petani berpikir dua kali dalam melaksanakan pertanian organik.

Hasil produksi beras organik yang dilakukan oleh anggota petani KNOC selalu mengalami fluktuasi. Fluktuasi produksi beras organik terjadi akibat adanya penyimpangan produksi ataupun anggota petani yang mengalami penurunan untuk menanam padi organik.berdasarkan Tabel 2 dapat diketahui bahwa dari tahun 2014 hingga tahun 2015 jumlah setoran gabah oleh petani anggota KNOC mengalami penurunan. Baik padi putih, padi merah, maupun padi hitam.

Berdasarkan Tabel 3 dapat diketahui pula bahwa jumlah petani yang menanam padi organik mengalami penurunan di setiap musim tanamnya, dari tahun 2014 hingga tahun 2015. Anggota KNOC mengalami penurunan yang cukup besar dari panen bulan Oktober dimana pada panen bulan Oktober jumlah petani yang meyetorkan gabah ke KNOC berjumlah 41 petani, namun pada panen bulan Februari jumlah petani yang menyetorkan gabah ke KNOC hanya berjumlah 14 petani. 
Agrisaintifika

Jurnal Ilmu-Ilmu Pertanian

Vol. 2, No. 1, 2018

Marhaen, et al. 2018

Tabel 2. Jumlah Setoran Gabah Anggota KNOC Tahun 2014 dan tahun 2015

\begin{tabular}{clccc}
\hline \multirow{2}{*}{ Tahun } & \multirow{2}{*}{ Keterangan } & \multicolumn{3}{c}{ Jumlah Setoran Gabah (kg) } \\
\cline { 3 - 5 } & & Padi Putih & Padi Merah & Padi Hitam \\
\hline \multirow{2}{*}{2014} & Musim Tanam I & $46.429,5$ & $25.197,9$ & - \\
& Musim Tanam II & $34.184,5$ & $4.686,5$ & $3.235,9$ \\
& Musim Tanam III & 21.476 & 12.251 & 2.859 \\
\hline \multirow{2}{*}{2015} & Musim Tanam I & $11.450,7$ & $12.578,2$ & $1.050,7$ \\
& Musim Tanam II & $9.932,4$ & 10.204 & - \\
\hline
\end{tabular}

Sumber : Analisis Data Primer

Tabel 3.Jumlah Petani yang Menjadi Anggota KNOC Tahun 2014 dan Tahun 2015

\begin{tabular}{ccccc}
\hline \multirow{2}{*}{ Tahun } & \multirow{2}{*}{ Keterangan } & \multicolumn{3}{c}{ Jumlah Petani (orang) } \\
\cline { 3 - 5 } & & Padi Putih & Padi Merah & Padi Hitam \\
\hline \multirow{2}{*}{2014} & Musim Tanam I & 29 & 12 & - \\
& Musim Tanam II & 21 & 5 & 3 \\
& Musim Tanam III & 13 & 5 & 1 \\
\hline \multirow{2}{*}{2015} & Musim Tanam I & 7 & 6 & 1 \\
& Musim Tanam II & 5 & 8 & - \\
\hline
\end{tabular}

Sumber : Analisis Data Primer

Berdasarkan permasalahan yang ada maka penelitian ini dilakukan dengan tujuan untuk menganalisis keragaan pendapatan petani padi organik dan petani padi konvensional, mengetahui faktor penyebab apa yang paling utama menyebabkan menurunnya minat petani menanam padi organik, serta mencari tindakan apa yang dapat meningkatkan minat petani menanam padi organik.

\section{METODE PENELITIAN}

Metode dasar penelitian yang digunakan adalah metode deskriptif. Metode penentuan masalah menggunakan metode observasi. Lokasi penelitian di Kabupaten Ngawi. Lokasi ini dipilih karena merupakan salah satu sentra penghasil padi di Jawa Timur dan saat ini mulai membudidayakan padi organik.

\subsection{Metode Penentuan Sampel}

Metode penentuan sampel terdiri dari penentuan responden dan penentuan informan.Metode penentuan responden petani padi organik menggunakan metode sensus sedangkan metode penentuan responden petani padi konvensional menggunakan metode proportional random sampling. Penentuan informan dilakukan dengan metode snowball sampling.

\subsection{Jenis Data dan Teknik Pengumpulan data}

Penelitian ini menggunakan data primer dan data sekunder. Data primer merupakan data yang diperoleh langsung dari responden melalui proses mengumpulan data. Data sekunder merupakan data penunjang berbentuk arsip yang diperoleh dari instansi terkait.Teknik pengumpulan data yang digunakan dalam penelitian ini adalah observasi, wawancara, kuisioner, serta dokumentasi dan pencatatan.

\subsection{Metode Analisis Data}

\subsubsection{Analisis Usahatani}

Penelitian ini menggunakan konsep biaya mengusahakan dimana biaya mengusahakan merupakan biaya alat-alat luar ditambah dengan upah tenaga kerja keluarga sendiri yang diperhitungkan sesuai dengan upah yang dibayarkan kepada tenaga kerja luar.

Perhitungan Penerimaan adalah perkalian antara produksi yang dihasilkan oleh petani dengan harga jual yang berlaku (Rahim et al, 2007). 
Agrisaintifika

Perhitungan Pendapatan merupakan selisih dari penerimaan dengan biaya yang dikeluarkan oleh petani.

Efisiensi usahatani merupakan nilai yang menunjukkan ushatani tersebut efisien atau tidak. Nilai ini didapatkan dari nisbah total penerimaan (total revenue) dengan total biaya (total cost) usahatani (TR/TCratio). Apabila nilai efisiensi lebih besar dari satu maka menunjukkan bahwa usahatani tersebut efisien

\subsubsection{Analisis Fishbone Diagram}

Diagram sebab akibat menggambarkan garis dan simbol-simbol yang menunjukkan hubungan antara sebab dan akibat suatu masalah. Diagram ini digunakan untuk mengetahui akibat dari suatu masalah yang selanjutnya diambil tindakan untuk diperbaiki. Dari akibat tersebut kemudian dicari kemungkinan beberapa penyebabnya. Penyebab masalah ini pun dapat berasal dari berbagai sumber utama, misalnya metode kerja, bahan, pengukuran, karyawan, lingkungan, dan seterusnya (Ariani, 2005). Setalah dilakukan analisis maka kemudian menentukan rekomendasi atau usulan tindakan untuk mengatasi permasalahan dari setiap faktor yang sebelumnya telah dianalisis dalam fishbone diagram.

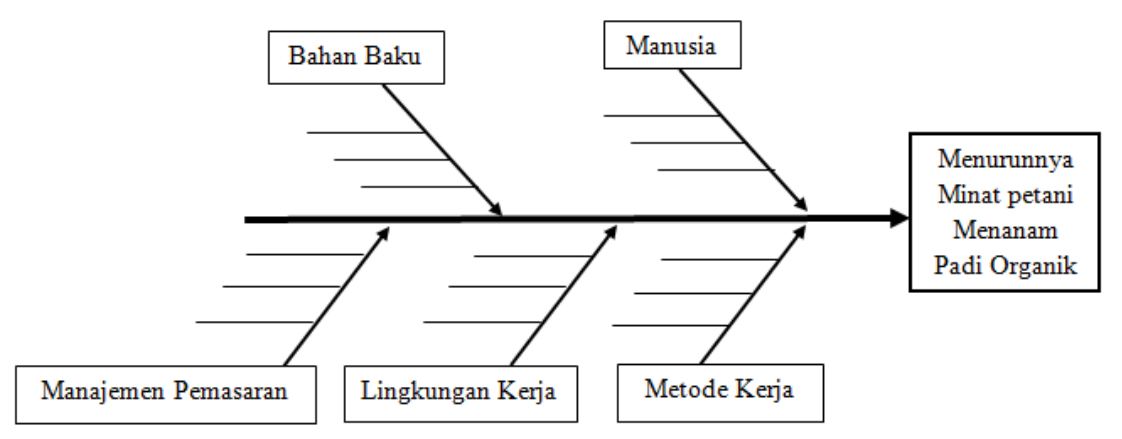

Gambar 1. Fishbone Diagram

Tabel 4.Tindakan Perbaikan Permasalahan

\begin{tabular}{|c|c|c|c|}
\hline Faktor yang diamati & $\begin{array}{l}\text { Masalah } \\
\text { terjadi }\end{array}$ & yang & $\begin{array}{c}\text { Tindakan } \\
\text { Perbaikan }\end{array}$ \\
\hline $\begin{array}{l}\text { Manusia } \\
\text { Bahan baku } \\
\text { Metode Kerja } \\
\text { Lingkungan Kerja } \\
\text { Manajemen Pemasaran }\end{array}$ & & & \\
\hline
\end{tabular}

\section{HASIL DAN PEMBAHASAN}

\subsection{Keragaan Pendapatan Usahatani Padi Organik dan konvensional}

Berdasarkan Tabel 5 dapat diketahui bahwa rata-rata total biaya sarana produksi usahatani padi organik per hektar adalah Rp. 3.374.156,25. Rata-rata total biaya sarana produksi usahatani padi konvensional per hektar adalah Rp. 2.964.628,41. Berdasarkan rata-rata total biaya sarana produksi usahatani per hektar, usahatani organik memiliki rata-rata total biaya lebih tinggi dibandingan dengan rata-rata total biaya milik usahatani konvensional. Perbedaan yang paling nampak adalah pada biaya pupuk dan pestisida. Kedua biaya ini memperlihatkan bahwa usahatani konvensional lebih efisien 
Agrisaintifika

Jurnal Ilmu-Ilmu Pertanian

Vol. 2, No. 1, 2018

Marhaen, et al. 2018

dalam input dibandingkan dengan usahatani organik.

usahatani konvensional per hektar, yaitu sebesar $5338,91 \mathrm{~kg}$ dan $7490,30 \mathrm{~kg}$.

Berdasarkan Tabel 6 dapat diketahui rata-rata jumlah produksi usahatani organik juga lebih rendah didandingkan dengan

Tabel 5. Rata-Rata Biaya Usahatani Padi Organik dan Konvensional per Hektar di Ds. Guyung, Kec. Gereh, Kab. Ngawi Pada Musim Tanam 1 tahun 2015

\begin{tabular}{|c|c|c|c|}
\hline \multirow{2}{*}{ No } & \multirow{2}{*}{ Uraian Biaya } & \multicolumn{2}{|c|}{ Petani } \\
\hline & & Organik & Konvensional \\
\hline \multirow[t]{10}{*}{1} & Sarana Produksi & & \\
\hline & a. Benih & & $382.101,27$ \\
\hline & b. Pupuk & & \\
\hline & 1) Pupuk Kimia & _ & $1.637 .781,74$ \\
\hline & 2) Pupuk Organik & $3.024 .694,99$ & $515.684,54$ \\
\hline & c. Pestisida & & \\
\hline & 1) Pestisida Kimia & - & $2.319 .66,73$ \\
\hline & $\begin{array}{l}\text { 2) Pestisida } \\
\text { Orqanik }\end{array}$ & - & $515.684,54$ \\
\hline & d. Penyusutan Alat & $987.78,30$ & $78.555,90$ \\
\hline & Sub Total Biaya & $3.374 .156,25$ & $2.964 .628,41$ \\
\hline \multirow[t]{14}{*}{2} & Tenaga Kerja & & \\
\hline & a. Pengolahan Tanah & & \\
\hline & 1) Mencangkul & $333.764,12$ & $231.897,95$ \\
\hline & 2) Membajak & $1.493 .476,25$ & $876.544,72$ \\
\hline & b. Persemaian Bibit & $144.338,57$ & $69.887,57$ \\
\hline & c. Penanaman & $966.580,53$ & $681.301,81$ \\
\hline & d. Pemeliharaan & & \\
\hline & 1) Pemupukan & $651.080,1$ & $339.710,19$ \\
\hline & 2) Penyiangan & $2.735 .157,34$ & $265.290,40$ \\
\hline & $\begin{array}{l}\text { 3) Pengendalian } \\
\text { HPT }\end{array}$ & $2.531 .320,91$ & $164.952,40$ \\
\hline & 4) Pengairan & $600.509,66$ & 22.80375 \\
\hline & e. Panen & $2.261 .059,39$ & $3.328 .000,59$ \\
\hline & f. Pengangkutan & $240.726,45$ & $199.010,95$ \\
\hline & Sub Total Biaya & $11.958 .013,33$ & 7.333.342,76 \\
\hline \multirow[t]{5}{*}{3} & Biaya Lain Lain & & \\
\hline & a. Pajak Tanah & $31.992,91$ & $33.363,49$ \\
\hline & b. Selametan & & \\
\hline & Sub Total Biaya & $31.992,91$ & $33.363,49$ \\
\hline & Total Biaya & $15.364 .162,49$ & $10.331 .334,66$ \\
\hline
\end{tabular}

Sumber : Analisis Data Primer

Tabel 6.Rata-Rata Penerimaan Usahatani Padi Organik dan Konvensional di Ds. Guyung, Kec. Gereh, Kab. Ngawi Pada Musim Tanam 1 tahun 2015

\begin{tabular}{llcc}
\hline \multirow{2}{*}{ No } & \multicolumn{1}{c}{ Uraian } & \multicolumn{2}{c}{ Petani } \\
\cline { 2 - 4 } & & Organik/ Ha & Konvensional/ Ha \\
\hline 1 & Produksi (kg) & 5338,91 & 7490,30 \\
2 & Harga (Rp/Kg) & 5000,00 & 3800,00 \\
3 & Penerimaan (Rp) & $26.694 .561,83$ & $28.463 .152,32$ \\
\hline
\end{tabular}

Sumber : Analisis Data Primer 
Agrisaintifika

Jurnal Ilmu-Ilmu Pertanian

Vol. 2, No. 1, 2018

Marhaen, et al. 2018

Tabel 7. Rata-Rata Pendapatan Usahatani Padi Organik dan Konvensional per Hektar di Ds.

Guyung, Kec. Gereh, Kab. Ngawi Pada Musim Tanam 1 tahun 2015

\begin{tabular}{llcl}
\hline \multirow{2}{*}{ No. } & \multicolumn{1}{c}{ Uraian } & \multicolumn{2}{c}{ Petani } \\
\cline { 2 - 4 } & Penerimaan (Rp) & $26.694 .561,83$ & Konvensional \\
\hline 1 & Biaya (Rp) & $15.364 .162,49$ & $28.463 .152,32$ \\
2 & Ben & $10.331 .334,66$ \\
3 & Pendapatan (Rp) & $11.330 .399,35$ & $18.131 .817,66$ \\
\hline
\end{tabular}

Sumber : Analisis Data Primer

Berdasarkan Tabel 7 dapat diketahui pula bahwa rata-rata pendapatan usahatani organik per hektar adalah Rp. 11.330.399,35. sedangkan rata-rata pendapatan konvensional per hektar adalah Rp. 18.131.817,66. Selisih dari rata-rata pendapatan usahatani keduanya adalah $\mathrm{Rp}$. 6.801.418,31.

Berdasarkan perhitungan $\mathrm{R} / \mathrm{C}$ ratio diketahui bahwa usahtani padi organik memiliki nilai 2,01 yang berarti bawha usahatani padi organik sudah efisien. Sama halnya dengan usahatani organik, usahatani konvensional juga sudah efisien dengan nilai $\mathrm{R} / \mathrm{C}$ ratio 3,09 . Hal ini menunjukkan bahwa meskipun kedua usahatani merupakan usahatani yang sudah efisien namun tingkat keefisienan usahatani organik lebih rendah apabila dibandingkan dengan usahatani konvensional.
Berdasarkan perhitungan nilai IBCR diketahui bahwa nilai IBCR adalah - 1,40. Sesuai dengan kriteria apabila nila IBCR < 1maka usahatani padi organik tidak lebih bermanfaat / tidak lebih bagus apabila dibandingkan dengan usahatani padi konvensional. Dapat dikatakan pula bahwa usahatani organik tidak layak diterima menjadi alternatif usahatani atau usahatani padi organik tidak memiliki manfaat lebih apabila dibandingkan dengan usahatani konvensional.

\subsection{Faktor Utama Penyebab Menurunnya Minat Petani Menanam Padi Organik}

Faktor-faktor yang digunakan untuk mengetahui penyebab menurunya minat petani menanam padi organik dalam penelitian ini adalah terdiri dari manusia, bahan baku, metode kerja, lingkungan kerja, dan manajemen pemasaran.

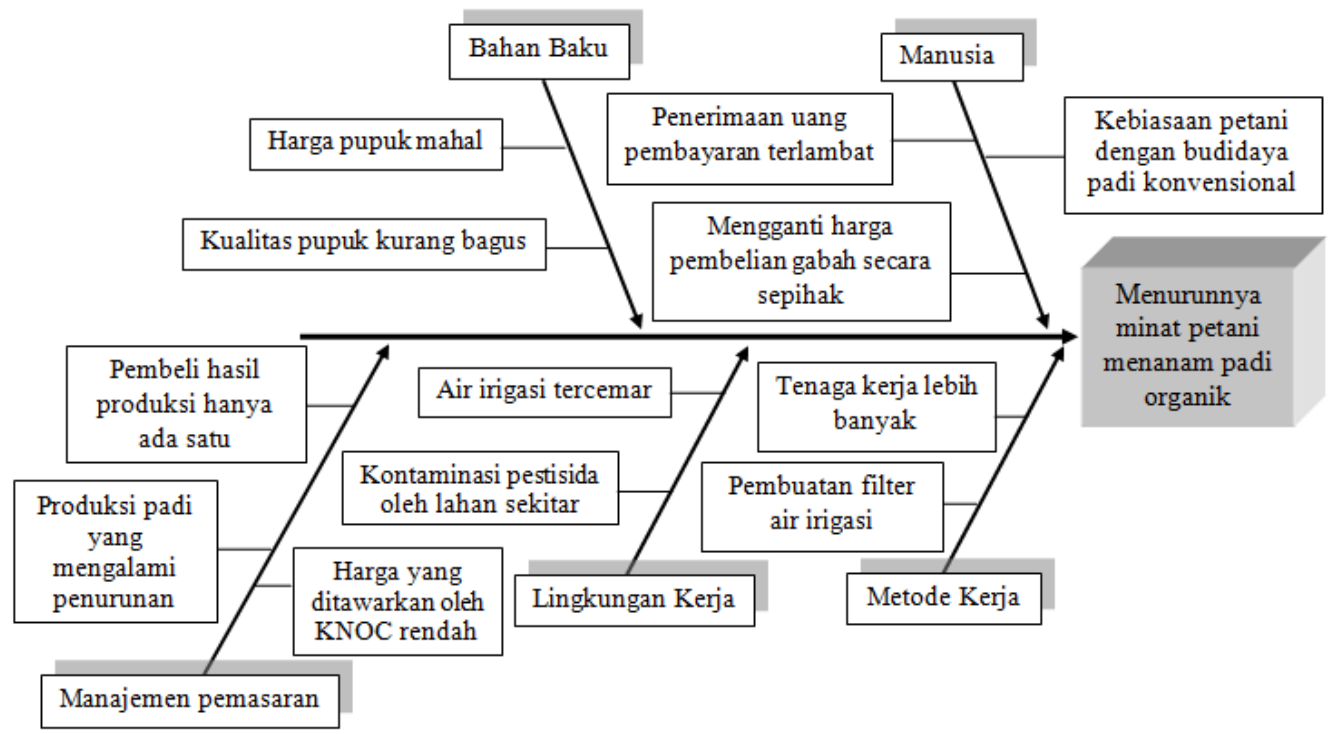

Gambar 2. Fishbone Diagram

Berdasarkan analisis fishbone diagram, yang menjadi faktor utama menurunnya minat petani menanam padi organik adalah penerimaan uang pembayaran yang terlambat. Berbeda dengan hasil penelitian Sukristiyonubuwono et al (2011),alasan 
Agrisaintifika

petanidi Kabupaten Ngawi untuk memilih membudidayakan padi organik adalah karena harga penjualan yang ditawarkan memiliki selisih yang lumayan apabila dibandingkan dengan harga jual padi konvensional. Petani pada saat panen pun akan berharap akan segera mendapatkan uang untuk kebutuhan mereka. Petani padi organik pun juga akan berharap pada saat panen mereka akan mendapatkan uang penjualan langsung pada saat setelah melakukan penyetoran gabah pada KNOC. Adanya penundaan pembayaran membuat para petani merasa kecewa dan tingkat kepercayaan pun akan menurun. Adanya penundaan pembayaran juga akan membuat petani was-was akan pembayaran yang akan diterimannya karena pada saat itu pihak KNOC belum memiliki pangsa pasar yang sesuai dengan target penjualan. Ketidakadaanya pangsa pasar membuat KNOC tidak mampu membayar pembelian gabah secara langsung kepada para petani organik.

Permasalahan seperti ini hendaknya tidak menjadikan menurunnya kepercayaan petani terhadap KNOC. Pihak KNOC, terutama pimpinannya, hendaknya mampu mengomunikasikan dengan baik (Salehi, 2012) mengenai sebab terjadinya permasalahan tersebut. Seorang pemimpin juga hendaknya mampu membangun kepercayaan dan selalu menganut etika bisnis yang baik, karena kepercayaan (Debora, 2013) dan etika bisnis yang baik akan berpengaruh positif pada komitmen anggota organisasi (Novianti, 2010).

Permasalahan pada metode kerja, bahan baku, lingkungan kerja masih dapat diperbaiki, karena berdasarkan hasil wawancara petani menanam padi organik hanya mengikuti perintah saja. Petani tidak melakukan inovasi sendiri, semua dilakukan atas dasar apa yang telah ditetapkan oleh KNOC, sehingga apabila petani memiliki niat untuk ikut dalam naungan KNOC maka mereka akan ikut saja tanpa protes terlalu lebih mengenai apa yang telah ditetapkan dan disepakati sebelumnya.

\subsection{Tindakan yang Dapat Meningkatkan Minat Petani Mananam padi Organik}

Tindakan yang dapat meningkatkan minat petani dirumuskan berdasarkan dari hasil wawancara yang telah dilakukan. Tindakantindakan tersebut juga berasal dari beberapa gagasan responden yang sekirannya dapat digunakan sebagai tindakan perbaikan dari masalah yang terjadi. Perumusan tindakan perbaikan juga dilakukan dengan melihat kondisi di lapangan untuk menyesuaikan tindakan tersebut akan menjadi salah satu solusi guna menyelesaikan permasalahan yang terjadi.

Tabel 4.Tindakan Perbaikan Masalah

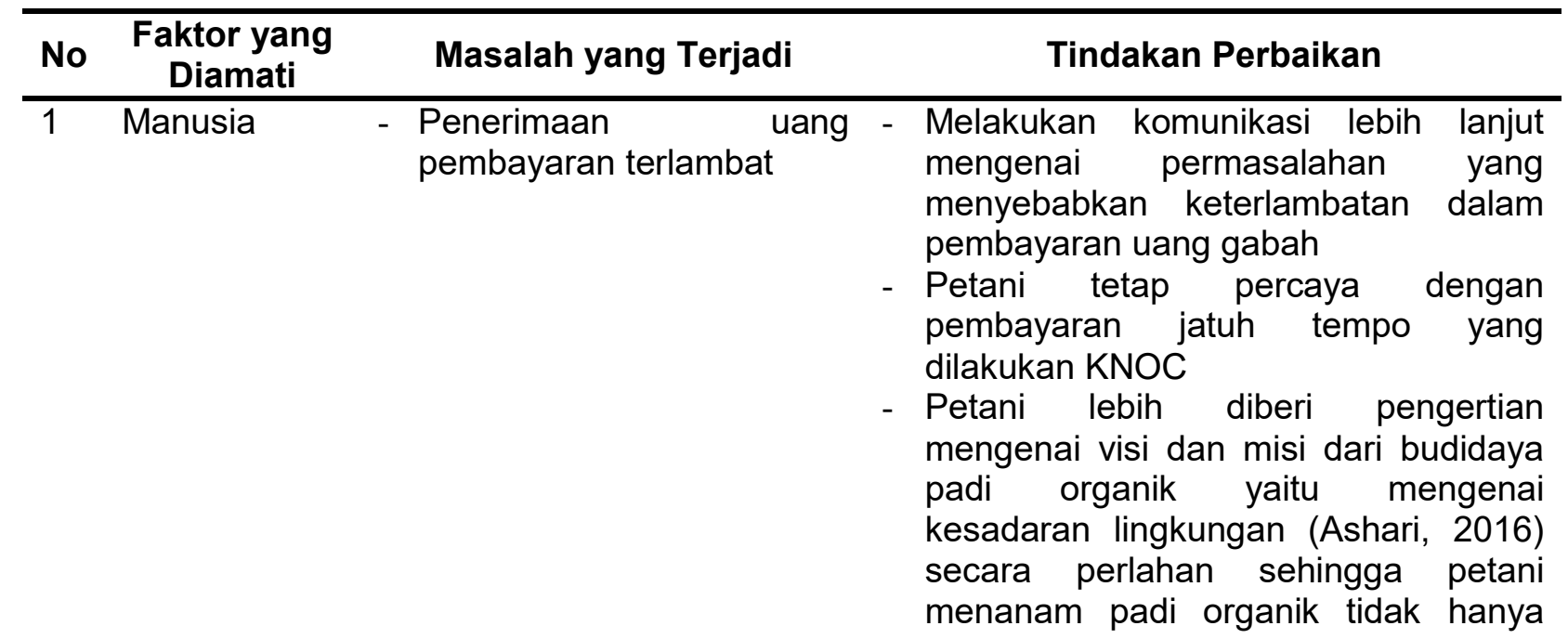


Agrisaintifika

Jurnal Ilmu-Ilmu Pertanian

Vol. 2, No. 1, 2018

Marhaen, et al. 2018

- Kebiasaan petani dengan budidaya padi konvensional

- Mengganti pembelian gabah secara sepihak

2 Bahan baku - Harga pupuk mahal

- Kualitas pupuk kurang bagus

Metode kerja

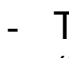

- Pembuatan filter air irigasi

Lingkungan kerja pada orientasi pendapatan

Member penjelasan mengenai dampak positif dan negatif dari budidaya padi organik agar petani mengerti mengenai resiko dan manfaatnya sejak awal

- Memikirkan inovasi yang membuat budidaya padi organik lebih efisen

- Tidak melanggar kontrak yang sudah disepakati (Novianti, 2010)

- Melakukan komunikasi dua arah (Sajuwitaningtyas, 2014) apabila memang harus merubah isi kontrak

- Menjelaskan secara detail mengenai sebab apabila melakukan perubahan kontrak dan memberikan solusi yang bersifat win-win solution

- Meningkatkan jumlah subsisdi pupuk

- Petani ikut memberikan masukan hara ke lahan dengan cara mendekomposisi jerami (Rusiyah et al, ) untuk menghemat kebutuhan pupuk yang dibeli

- Melakukan perbaikan kualitas pupuk dengan menambah zat organik yang diperlukan oleh lahan pertanian

- Tetap mengikuti sesuai anjuran ke lahan, karena intensitas ke lahan mempengaruhi hasil dari produksi usahatani

- Membuat inovasi mengenai peningkatan kemampuan MOL dalam penanggulangan dan pencegahan hama penyakit

- Mengajak petani yang lebih muda untuk melakukan budidaya padi organik

- Mengambil ke sumber air yang langsung berasal dari sumur

- Membuat sumur sendiri yang dialirkan ke lahan sawah organik

- Membuka lahan baru di kawasan dekat dengan sumber air murni

- Membuat filter air

- Melakukan Bioremediasi dengan mikroorganisme atau enzim yang mampu mendegradasi bahan pencemar (Sutanto, 2001)

- Membuat sumur khusus yang akan dialirkan ke lahan sawah organik

- Kontaminasi pestisida oleh - Member pengertian kepada petani lahan sekitar yang menyemprot pestisida untuk menghadap ke tengah lahan sehingga pestisida tidak mengkontaminasi lahan 
Agrisaintifika

Jurnal Ilmu-Ilmu Pertanian

Vol. 2, No. 1, 2018

Marhaen, et al. 2018

5 Manajemen Pemasaran Pembeli hasil
hanya ada satu sawah organik

- Memberikan MOL sebagai pengganti pestisida kimia

- Membuat batas sawah dengan kelambu atau plastik

produksi - Diharapkan di Kabupaten Ngawi terdapat lembaga swadaya organik lainnya yang mampu mengakomodasi para petani ynag ingin menanam padi organik

- Petani yang telah memiliki kemampuan baik dalam bidang financial ataupun pengetahuan mau untuk melakukan pemasaran secara mandiri sehingga petani tidak hanya menjual dalam bentuk gabah namun juga dalam bentuk beras

- Produksi padi yang (Safitri, 2013)

Perlu adanya inovasi dari KNOC yang meminimalisir penurunan produksi padi organik dari lahan yang baru beralih dari budidaya padi konvensional ke budidaya padi organik

- Member penjelasan mengenai dampak positif dan negatif dari budidaya padi organik agar petani mengerti mengenai resiko dan manfaatnya sejak awal

- Harga yang ditawarkan - Perlu adanya komunikasi lebih lanjut oleh KNOC rendah untuk penenetuan harga jual gabah yang diterima petani

- Penentuan harga hendaknya menyesuaikan harga beras organik dipasaran sehingga bersifat meningkatkan kesejahteraan petani (Nurasa, 2013)

Sumber : Analisis Data Primer

\section{KESIMPULAN}

Berdasarkan analisis keragaan usahatani dapat diketahui bahwa rata-rata biaya usahatani padi organik lebih tinggi apabila dibandingkan dengan usahatani padi konvensional. Rata-rata penerimaan usahatani padi organik lebih rendah apabila dibandingkan dengan usahatani padi konvensional. Rata-rata pendapatan usahatani padi organik lebih rendah apabila dibandingkan dengan usahatani padi konvensional. Nilai R/C ratio sebesar 2,01 menunjukkan bahwa usahatani padi organik telah efisien, namun nilai $\mathrm{R} / \mathrm{C}$ ratio lebih rendah dibandingkan dengan nilai $\mathrm{R} / \mathrm{C}$ ratio dari usahatani padi konvensional, yaitu 3,09.
Nilai IBCR adalah $-1,40$, artinya usahatani organik tidak memiliki manfaat lebih / lebih bagus apabila dibandingkan dengan usahatani padi konvensional.

Penyebab utama dari penurunnya minat petani menanam padi organik adalah penerimaan uang pembayaran yang terlambat. Tindakan yang dapat meningkatkan minat petani menanam padi organik di Kabupaten Ngawi berdasarkan farktor penyebab utamannya adalah melakukan komuniasi lebih lanjut mengenai permasalahan yang menyebabkan keterlambatan dalam pembayaran uang gabah, petani tetap percaya dengan pembayaran jatuh tempo yang dilakukan 
Agrisaintifika

Jurnal Ilmu-Ilmu Pertanian

Vol. 2, No. 1, 2018

Marhaen, et al. 2018

KNOC, serta petani lebih diberi pengertian mengenai visi dan misi dari budidaya padi organik secara perlahan sehingga petani menanam padi organik tidak hanya pada orientasi pendapatan.

Saran yang dapat diberikan adalah membangun komunikasi lebih lanjut karena komunikasu merupakan faktor penting untuk menghindari kesalahpahaman, oleh karena itu hendaknya KNOC menjaga komunikasi dengan pihak petani. Hal ini juga akan membuat petani merasa dihargai apabila setiap ada permasalahan petani mengetahui dan petani akan merasa menjadi bagian dari lembaga. KNOC hendaknya juga dalam setiap menentukan solusi permasalahan yang berhubungan dengan petani hendaknya melibatkan petani serta solusi yang ditentukan pun bersifat win-win solution.

\section{DAFTAR PUSTAKA}

Amrullah, S. 2005. Beras dalam Dinamika Ekonomi Politik. Majalah Pangan44(27): 48-59.

Andoko, A. 2010.Budidaya Padi Secara Organik. Jakarta: Penebar Swadaya.

Ashari. 2016. Rice Farmer's Preception and Attitude Toward Organic Farming Adaption. Jurnal Agro Ekonomi 34(1): 35-46.

BPS Ngawi. 2013. Kabupaten Ngawi dalam Angka.Ngawi: BPS.

Debora, Maria dan Mutia Ismail. 2013. Implikasi Akuntansi Lingkungan serta Etika Bisnis Sebagai Faktor Keberlangsungan Perusahaan di Indonesia. Jurnal Akuntansiku 2(1).

Mayrowani, Henny. 2012. Pengembangan Pertanian Organik di Indonesia. Forum Penelitian Agro Ekonomi 30(2):91-108.

Novianti, Leny., dan Hendra Gunawan. 2010. Pengaruh Etika Kerja Islam dan Etika Bisnis Terhadap Komitmen Organisasi dengan Komitmen Profesi
Sebagai Variabel Intervening. Manajemen Teori dan Terapan 3(2).

Nurasa, Tjetjep., dan Muchjidi Rachmat. 2013. Nilai Tukar Petani Padi di Beberapa Sentra Produksi Padi di Indonesia. Jurnal Agro Ekonomi 31(2): 161-179.

Purwanto, E. 2012.Fisiologi Stres Lingkungan Tanaman Budidaya. Surakarta: UNS Press.

Rahim A., Diah R.W dan Hastuti 2007. Pengantar Teori dan Kasus Ekonomika Pertanian. Jakarta : Penebar Swadaya.

Rusiyah, MR. Djarot SW, Tukidal Y. 2012. Studi Pengembangan Pertanian Padi Sawah Organik Berdasarkan Kesesuaian Lahan dan Potensi Pupuk Organik Dari Limbah Pertanian di Kecamatan Temon, Kabupaten Kulonprogo. MGI 26(2): 190-203.

Safitri, Sri., Diana Chalil, dan Emalisa. 2013. Strategi Pengembangan Sistem Agribisnis Beras Organik (Studi Kasus: Desa Lubuk Bayas Kecamatan Perbaungan Kabupaten Serdang Bedagai). Social Economic of Agriculture and Agribusiness 2(10).

Salehi, Mehrdad., Motjaba Saeidina,Mohammadreza Aghaei. 2012. Business Ethics. International Journal of Scientific and Research Publications 2(1).

Sajuwitaningtyas, Riza. 2014. Faktor-Faktor Penghambat Partisipasi Penerima Manfaat Program Pemberdayaan Ekonomi Pada Kelompok Swadaya Masyarakat di Kelurahan Kalianak Kecamatan Asemwowo Kota Surabaya. Kebijakan dan Manajemen Publik 2(1).

Sukristiyonubuwono, Wiwik $H$, Sofyan A, Benito HP, de Neve S. 2011. Change from conventional to organic rice farming system: biophysical and socioeconomic reason. Int Res $J$ Agric Soil Sci 1(5):172-182. 
Agrisaintifika

Jurnal Ilmu-Ilmu Pertanian

Vol. 2, No. 1, 2018

Marhaen, et al. 2018

Sutanto, Rachman. 2001. Pencemaran Tanah dan Air Tanah oleh Pestisida dan Cara Menanggulanginya. Jurnal Perlindungan Tanaman Indonesia 7(1): 9-15.

Taufik, Imam. 2011. Pencemaran Pestisida Pada Perairan Perikanan di Sukabumi - Jawa Barat. Media Akuakultur 6(1): 69-75.

Utary, Tavy Supriana, dan Sri Fajar Ayu. 2013. Usahatani dan Strategi Pengembangan Pertanian Organik Vertikultur di Kecamatan Medan Marelan. Social Economic of Agriculture and Agribusiness 2(7). 